UDK 528.4

\title{
TOLIMAČIO GEOMETRINIŲ PARAMETRŲ TIKSLUMO IৃTAKOS MATUOJANT STATYBOS OBJEKTUS TYRIMAS
}

\author{
Renata Bagdžiūnaitè \\ Geodezijos ir kadastro katedra, Vilniaus Gedimino technikos universitetas, \\ Saulètekio al. 11, LT-10223 Vilnius-40, Lietuva, \\ el. paštas: renata@adm.vtu.lt \\ Iteikta 200401 09; priimta 20040614
}

\begin{abstract}
Santrauka. Darbe modeliavimo būdu tiriama tolimačio ašių nelygiagretumo itaka atliekant matavimus statybos aikštelėse, kai dirbama be prizminio reflektoriaus, esant skirtingiems parametrams tarp pagrindinių tolimačio ašių bei įvairioms matavimų sąlygoms. Ašių nelygiagretumo įtaka tiriama pagal jau taikomą ir pagal mūsų pasiūlytą metodikas. Skaičiavimai atlikti panaudojus ankstesnių tyrimų duomenis.
\end{abstract}

Raktažodžiai: atstumo pataisa, vizavimo ašies nuokrypis, horizontalusis necentriškumas, vertikalusis necentriškumas.

\section{1. İvadas}

Nūdienos statybose svarbu, kad matavimai būtų labai tikslūs. Jie atliekami specifinėmis, dažnai matuoti labai sudètingomis sąlygomis. Atliekant matavimus statybose, dažnai esti dideli vizavimo spindulio posvyrio kampai, vizavimo spinduliai ne visada statmeni plokštumai, i kurią vizuojama. Dèl geodeziniu prietaisu konstrukcinių ypatumų bei matavimų sąlygų atsiranda tam tikrų sistemingujų matavimo paklaidų.

Atliekant geodezinius matavimus statybose, kontrolinėms montavimo darbų nuotraukoms sudaryti, statybos konstrukcijų ir statiniu deformacijoms matuoti dažniausiai taikomi elektroniniai tolimačiai ir tacheometrai. Dirbti tolimačiais, kuriais matuojama su reflektoriais, statybose nepatogu, nes ne visada šias prizmes galima pastatyti matuojamame taške. Todèl patogiausia naudoti prietaisus, kuriems nereikalingi reflektoriai su prizmėmis. Tačiau dèl to gali atsirasti papildomų sistemingujų matavimo paklaidų. Ypač reikšmingos matavimo paklaidos, priklausančios nuo prietaisu konstrukciju, atliekant geodezinius darbus statybose esti dirbant su horizontaliojo ir vertikaliojo necentriškumo prietaisais [1]. Šių paklaidų itaka ir jų sumažinimo būdai nagrinèti [1-6] darbuose.

Naujausieji prietaisai konstruojami taip, kad nebūtu horizontaliojo bei vertikaliojo necentriškumo. Tačiau ir naujausiuose tolimačiuose tarp pagrindinių žiūrono ašių (optinès vizavimo ašies, tikrosios vizavimo ašies, atstumų matavimo linijos) yra tam tikro dydžio kampai (nelygiagretumas). Tai patvirtina tolimačių patikros rezultatai. Todèl labai aktualu yra ívertinti ašių nelygiagretumo įtaką matavimų rezultatams.

Teoriniai tolimačio ašių nelygiagretumo ittakos matavimu rezultatams klausimai nagrinèti [1, 4-6] darbuose.

Šio darbo tikslas - remiantis [6] darbe pateikta tolimačio ašių nelygiagretumo ittakos išmatuotiems atstumams įvertinimo teorija modeliavimo būdu ištirti dèl tolimačio ašių nelygiagretumo atsirandančias matavimo statybose duomenų paklaidas bei išnagrinėti, ar gautieji rezultatai atitinka geodezinių matavimu statybose reikalavimus, reglamentuojamus statybos taisyklèse [7].

\section{Tolimačio ašių nelygiagretumo įtakos išmatuotiems atstumams tyrimas}

Paklaidos, kurioms ittakos turi tolimačio ašių (optinè vizavimo ašis, tikroji vizavimo ašis, atstumų matavimo linija) nelygiagretumas, atliekant matavimus statybose nagrinètos modeliuojant. Paklaidos apskaičiuotos pagal [6] išdèstytą metodiką.

Pagal [1] išdèstytą metodiką galima apskaičiuoti atstumo pataisą taške dẻl prietaiso ašių nelygiagretumo horizontaliosios komponentès (kampai tarp pagrindinių tolimačio ašiu yra horizontaliojoje plokštumoje - 1 pav.). Bet tai nèra tikslu, nes tarp ašių kampas gali būti ir vertikaliaja kryptimi - gausime dèl prietaiso ašių nelygiagretumo atsirandančią vertikaliają atstumo paklaidos komponentę [6].

1 pav. $\lambda_{A}-$ kampas tarp atstumų matavimo linijos ir tikrosios vizavimo ašies; $\lambda_{K}-$ kampas tarp optinès ir tikrosios vizavimo ašies; $\theta-$ kampas tarp $x$ koordinatès ašies ir vizuojamosios plokštumos; $v$ - kampas tarp per prietaiso stovejjimo tašką išvestos vertikaliosios plokštumos, statmenos sienai, ir tikrosios vizavimo ašies; $O$ - prietaiso stovejjimo taškas.

Pastato modelyje numatyti 7 matavimo ženklai. Modeliuojant laikyta, kad prietaisas nuo 4-ojo matavimo ženklo pastatytas $17,658 \mathrm{~m}$ atstumu taip, kad kampas, kuri sudaro vizavimo spindulio plokštuma i 4-aji matavimo ženklą, su pastato siena būtų $90^{\circ}$ (2 pav.). Modeliuota su 7 viršutiniais matavimo ženklais. Skirtingais modeliavimo atvejais laikyta, kad vizavimo ašies kampinè nuokrypa horizontaliojoje ir vertikaliojoje plokštumose yra 10", 20", 30". Modeliuoti atstumai iki visų 7 viršutinių matavimo ženklų ir gautas išmatuotasis atstumas $S_{I S \check{M}}$. 


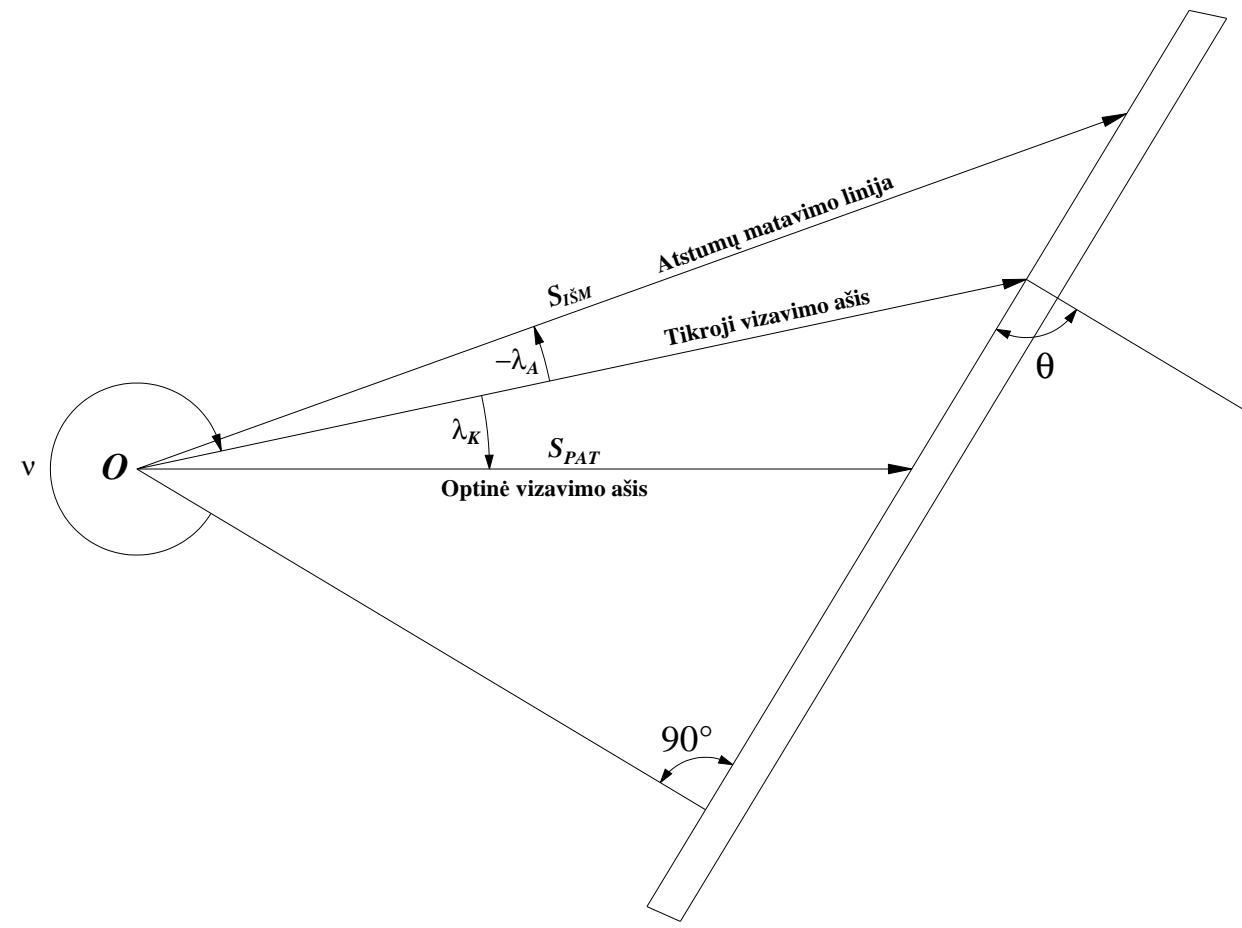

1 pav. Atstumo matavimo geometrinè schema (horizontalioji projekcija)

Fig 1. Geometric scheme or distance measurement (horizontal plane)

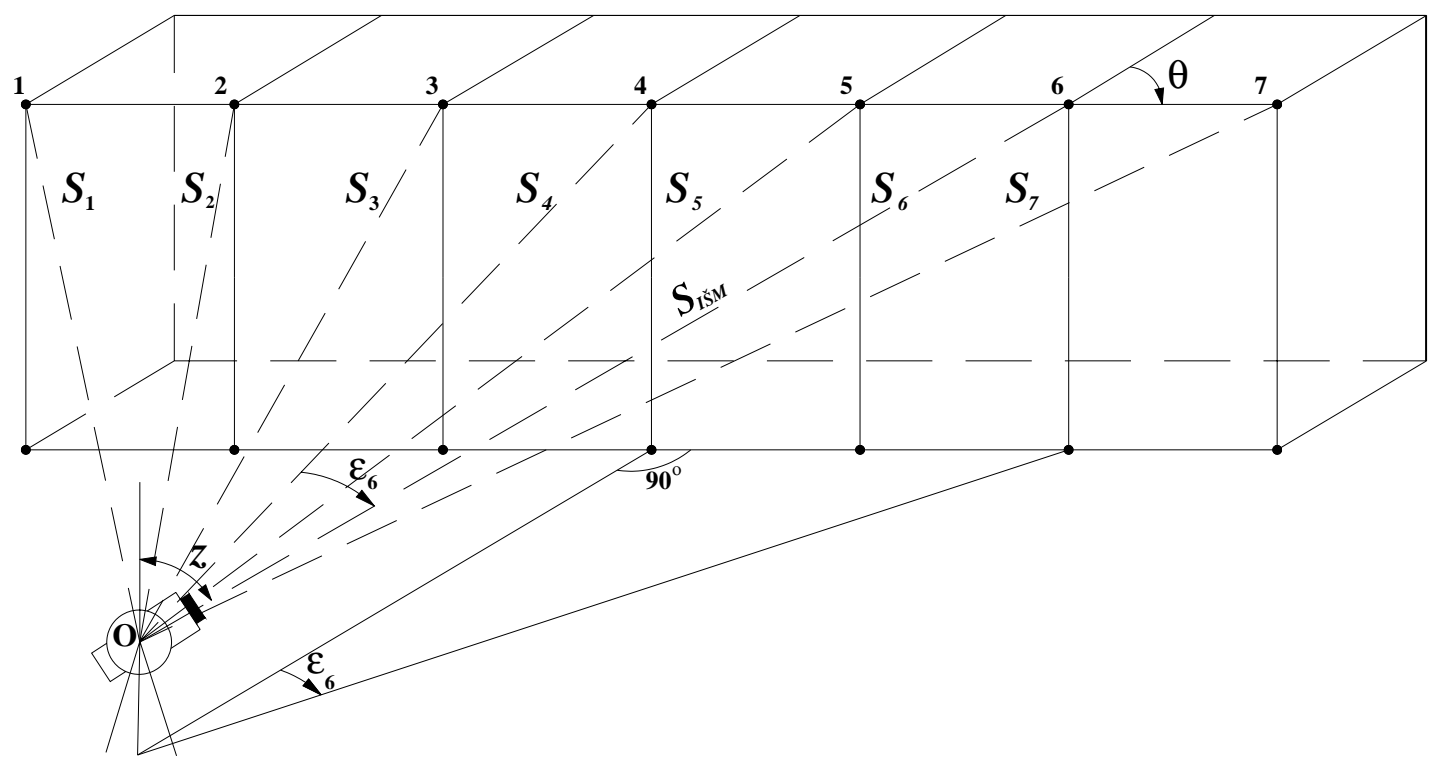

2 pav. Matavimų schema

Fig 2. Scheme of measurements

Skaičiuojant pagal pasiūlytą metodiką [6], ivertinama ir vizavimo ašies nuokrypio vertikalioji komponentė (bendras kampas tarp pagrindinių žiūrono ašių vertikaliojoje plokštumoje). Taikant [1] metodą ivertinama tik horizontalioji komponentè.

Skaičiavimai atlikti pagal [1] darbe pateiktą (1 lentelè) ir pagal mūsų pasiūlytą [6] (2 lentelè) metodikas. 1 -osios lentelès duomenys gauti pagal formulę [1]:

$$
\begin{aligned}
& S_{P A T}=S_{I \check{M} M} \cdot\left(\cos \left(\frac{\left(+\lambda_{K}\right)-\left(-\lambda_{A}\right)}{\sin z}\right)-\right. \\
& \left.-\sin \left(\frac{\left(+\lambda_{K}\right)-\left(-\lambda_{A}\right)}{\sin z}\right) \times \operatorname{ctg}\left(v-\theta+\frac{\lambda_{K}}{\sin z}\right)\right),
\end{aligned}
$$

čia $S_{I \check{M} M}-$ išmatuotas atstumas; $\lambda_{A}-$ kampas tarp atstumų matavimo linijos in tikrosios vizavimo ašies horizontaliojoje plokštumoje; $\lambda_{K}-$ kampas tarp optinès vizavimo ašies ir tikrosios vizavimo ašies horizontaliojoje plokštumoje; $\theta$ - kampas tarp per matuojamaji tašką išvesto statmens i pastato sieną ir vizuojamosios plokštumos; $v$ - kampas tarp per prietaiso stovejjimo tašką išvestos vertikaliosios plokštumos, statmenos sienai, ir tikrosios vizavimo ašies; $\varepsilon$ - kampas tarp per prietaiso stovèjimo tašką išvestos vertikaliosios plokštumos, statmenos pastato sienai, ir per atstumo matavimo liniją išvestos vertikaliosios plokštumos, skaičiuojamas laikrodžio rodyklès kryptimi. Kampo $\lambda_{A}$ ir $\lambda_{K}$ reikšmès taikomos 10", 20", 30". Matavimų schema pateikta 2 pav. 
Zenitinio kampo reikšmè kito nuo $65^{\circ}$ iki $70^{\circ}$. Iš 1 pav. matyti, kad $\lambda_{A}$ yra mažas kampas, taigi skaičiuojant galima laikyti, $\operatorname{kad} v \approx \varepsilon$.

Iš pateiktų rezultatų matyti, kad didèjant kampams $\lambda_{A}$ ir $\lambda_{K}$ tarp ašių didèja dèl ašių nelygiagretumo horizontaliaja kryptimi atsirandančios atstumo paklaidos reikšmè. Atstumo paklaidos reikšmė dar priklauso ir nuo kampo $\varepsilon$. Didèjant šio kampo reikšmei labai skiriasi išmatuotos linijos reikšmė nuo apskaičiuotos pataisytos. Šiuo atveju mažai kintantis zenitinis kampas didelès itakos nedaro.

Išmatuotieji ir pataisytieji atstumai skiriasi nuo \pm 1 iki $\pm 8 \mathrm{~mm}$. Atstumo paklaidos reikšmé didžiausia esant kampams $\lambda_{A}$ ir $\lambda_{K}$ tarp ašių horizontalia kryptimi $30^{\prime \prime}$.

Skaičiuojant pagal [6] darbe pasiūlytą metodiką, patikslintas atstumas gautas pagal formulę:

$$
\begin{aligned}
& S_{P A T(V, H)}=S_{I \check{M} M}+\frac{\lambda_{V}}{\rho} \cdot S_{I \check{M} M} \times \\
& \times \operatorname{tg}\left[(\gamma+z)-90^{\circ}\right]+ \\
& +\frac{\lambda_{H}}{\rho} \cdot S_{I \check{M} M} \cdot \operatorname{tg}\left[(\theta+\varepsilon)-90^{\circ}\right],
\end{aligned}
$$

1 lentelè. Ašių nelygiagretumo įtakos skaičiavimas (pagal [1] metodika)

\begin{tabular}{|c|c|c|c|c|c|c|}
\hline Linija & $\lambda_{\mathrm{V}} / \lambda_{\mathrm{A}}$ & $z$ & $\varepsilon$ & $\theta$ & $\begin{array}{l}S_{I \check{M} M} \\
(\mathbf{m})\end{array}$ & $\begin{array}{c}S_{P A T} \\
(\mathbf{m})\end{array}$ \\
\hline$S_{1}$ & \multirow{7}{*}{$10^{\prime \prime}$} & $70^{\circ}$ & $315^{\circ}$ & \multirow{7}{*}{$90^{\circ}$} & 25,252 & 25,249 \\
\hline$S_{2}$ & & $67^{\circ}$ & $326^{\circ}$ & & 21,364 & 21,363 \\
\hline$S_{3}$ & & $66^{\circ}$ & $341^{\circ}$ & & 18,656 & 18,655 \\
\hline$S_{4}$ & & $65^{\circ}$ & $180^{\circ}$ & & 17,658 & 17,658 \\
\hline$S_{5}$ & & $66^{\circ}$ & $19^{\circ}$ & & 18,642 & 18,643 \\
\hline$S_{6}$ & & $67^{\circ}$ & $34^{\circ}$ & & 21,335 & 21,336 \\
\hline$S_{7}$ & & $70^{\circ}$ & $45^{\circ}$ & & 25,204 & 25,206 \\
\hline$S_{1}$ & \multirow{7}{*}{$20^{\prime \prime}$} & $70^{\circ}$ & $315^{\circ}$ & \multirow{7}{*}{$90^{\circ}$} & 25,252 & 25,247 \\
\hline$S_{2}$ & & $67^{\circ}$ & $326^{\circ}$ & & 21,364 & 21,361 \\
\hline$S_{3}$ & & $66^{\circ}$ & $341^{\circ}$ & & 18,656 & 18,655 \\
\hline$S_{4}$ & & $65^{\circ}$ & $180^{\circ}$ & & 17,658 & 17,658 \\
\hline$S_{5}$ & & $66^{\circ}$ & $19^{\circ}$ & & 18,642 & 18,643 \\
\hline$S_{6}$ & & $67^{\circ}$ & $34^{\circ}$ & & 21,335 & 21,338 \\
\hline$S_{7}$ & & $70^{\circ}$ & $45^{\circ}$ & & 25,204 & 25,209 \\
\hline$S_{1}$ & \multirow{7}{*}{$30^{\prime \prime}$} & $70^{\circ}$ & $315^{\circ}$ & \multirow{7}{*}{$90^{\circ}$} & 25,252 & 25,244 \\
\hline$S_{2}$ & & $67^{\circ}$ & $326^{\circ}$ & & 21,364 & 21,36 \\
\hline$S_{3}$ & & $66^{\circ}$ & $341^{\circ}$ & & 18,656 & 18,654 \\
\hline$S_{4}$ & & $65^{\circ}$ & $180^{\circ}$ & & 17,658 & 17,658 \\
\hline$S_{5}$ & & $66^{\circ}$ & $19^{\circ}$ & & 18,642 & 18,644 \\
\hline$S_{6}$ & & $67^{\circ}$ & $34^{\circ}$ & & 21,335 & 21,339 \\
\hline$S_{7}$ & & $70^{\circ}$ & $45^{\circ}$ & & 25,204 & 25,212 \\
\hline
\end{tabular}

Table 1. Calculation of the influence of axis unparallelism (according to the methods [1]) čia $\lambda_{\mathrm{V}}$ - vertikalusis kampas tarp atstumų matavimo linijos ir optinès vizavimo ašies; $\gamma$ - kampas tarp pastato plokštumos, i kurią vizuojame, ir vertikalès (pastato sienos posvyrio kampas). Kai siena vertikali, $\gamma=0 ; z-$ vizavimo spindulio zenitinis kampas; $\lambda_{H}$ - horizontalusis kampas tarp atstumu matavimo linijos ir optinès vizavimo ašies.

Apskaičiuoti rezultatai pateikti 2 lentelèje.

Iš pateiktų rezultatų, skaičiuojant pagal [6] darbe pasiūlytą metodiką, matyti, kad kai kampai tarp ašių $\lambda_{H}$ ir $\lambda_{V}$ yra po $10^{\prime \prime}$, ašių nesutapimas trumpiems atstumams turès palyginti mažai itakos, nes pataisytasis atstumas išliks toks pats arba sumažès $2 \mathrm{~mm}$. Tai priklauso nuo vizavimo ašies horizontaliojo posūkio kampo $\varepsilon$ bei zenitinio kampo $z$ ir nuo linijos nestatmenumo vizuojamam paviršiui. Didesnè įtaka atstumui bus tada, kai vizavimo spindulys bus nestatmenas vizuojamam paviršiui. Šiuo atveju nuo prietaiso į abi puses labiausiai nutolę matavimo ženklai yra 1 ir 7 . Matuojant linijas $S_{1}$, ir $S_{7}$ - vizavimo spindulys nestatmenas matuojamam paviršiui (2 pav.), ir šioks toks vizavimo spindulio nestatmenumas itakos neturès, kai vizavimo spindulys bus beveik statmenas vizuojamam paviršiui.

2 lentelè. Ašiu nelygiagretumo itakos skaičiavimas (pagal [6] pasiūlytą metodika)

\begin{tabular}{|c|c|c|c|c|c|c|}
\hline Linija & $\lambda_{\mathrm{V}} / \lambda_{\mathrm{H}}$ & $z$ & $\varepsilon$ & $\theta$ & $\begin{array}{c}S_{I \check{S} M} \\
(\mathbf{m})\end{array}$ & $\begin{array}{c}S_{P A T} \\
(\mathbf{m})\end{array}$ \\
\hline$S_{1}$ & \multirow{7}{*}{$10^{\prime \prime}$} & $70^{\circ}$ & $315^{\circ}$ & & 25,252 & 25,250 \\
\hline$S_{2}$ & & $67^{\circ}$ & $326^{\circ}$ & & 21,364 & 21,363 \\
\hline$S_{3}$ & & $66^{\circ}$ & $341^{\circ}$ & & 18,656 & 18,655 \\
\hline$S_{4}$ & & $65^{\circ}$ & $180^{\circ}$ & $90^{\circ}$ & 17,658 & 17,658 \\
\hline$S_{5}$ & & $66^{\circ}$ & $19^{\circ}$ & & 18,642 & 18,642 \\
\hline$S_{6}$ & & $67^{\circ}$ & $34^{\circ}$ & & 21,335 & 21,335 \\
\hline$S_{7}$ & & $70^{\circ}$ & $45^{\circ}$ & & 25,204 & 25,205 \\
\hline$S_{1}$ & \multirow{7}{*}{$20^{\prime \prime}$} & $70^{\circ}$ & $315^{\circ}$ & & 25,252 & 25,249 \\
\hline$S_{2}$ & & $67^{\circ}$ & $326^{\circ}$ & & 21,364 & 21,362 \\
\hline$S_{3}$ & & $66^{\circ}$ & $341^{\circ}$ & & 18,656 & 18,655 \\
\hline$S_{4}$ & & $65^{\circ}$ & $180^{\circ}$ & $90^{\circ}$ & 17,658 & 17,657 \\
\hline$S_{5}$ & & $66^{\circ}$ & $19^{\circ}$ & & 18,642 & 18,642 \\
\hline$S_{6}$ & & $67^{\circ}$ & $34^{\circ}$ & & 21,335 & 21,335 \\
\hline$S_{7}$ & & $70^{\circ}$ & $45^{\circ}$ & & 25,204 & 25,206 \\
\hline$S_{1}$ & \multirow{7}{*}{$30^{\prime \prime}$} & $70^{\circ}$ & $315^{\circ}$ & & 25,252 & 25,247 \\
\hline$S_{2}$ & & $67^{\circ}$ & $326^{\circ}$ & & 21,364 & 21,361 \\
\hline$S_{3}$ & & $66^{\circ}$ & $341^{\circ}$ & & 18,656 & 18,654 \\
\hline$S_{4}$ & & $65^{\circ}$ & $180^{\circ}$ & $90^{\circ}$ & 17,658 & 17,657 \\
\hline$S_{5}$ & & $66^{\circ}$ & $19^{\circ}$ & & 18,642 & 18,642 \\
\hline$S_{6}$ & & $67^{\circ}$ & $34^{\circ}$ & & 21,335 & 21,336 \\
\hline$S_{7}$ & & $70^{\circ}$ & $45^{\circ}$ & & 25,204 & 25,206 \\
\hline
\end{tabular}

Table 2. Calculation of the influence of axis unparallelism (according to the methods [6]) 
3 lentelè. Paklaidų priklausomybė nuo vizavimo linijos zenitinio kampo

Table 3. Dependence of errors on the angle of line of sight

\begin{tabular}{|c|c|c|c|c|c|c|c|c|c|}
\hline \multirow{2}{*}{ Linija } & \multirow{2}{*}{$\lambda_{\mathrm{V}} / \lambda_{\mathrm{H}}$} & \multirow{2}{*}{$\varepsilon$} & \multirow{2}{*}{$\boldsymbol{\theta}$} & \multirow{2}{*}{$S_{I \check{M} M}$} & \multicolumn{2}{|c|}{ Atstumo pataisa (m) } & \multirow{2}{*}{$S_{I \check{M} M}$} & \multicolumn{2}{|c|}{ Atstumo pataisa (m) } \\
\hline & & & & & $z=67^{\circ}$ & $z=45^{\circ}$ & & $z=67^{\circ}$ & $z=45^{\circ}$ \\
\hline$S_{1}$ & \multirow{7}{*}{$20^{\prime \prime}$} & $315^{\circ}$ & \multirow{7}{*}{$90^{\circ}$} & 25,252 & $-0,003$ & $-0,003$ & 101,008 & $-0,014$ & $-0,020$ \\
\hline$S_{2}$ & & $326^{\circ}$ & & 21,364 & $-0,002$ & $-0,002$ & 85,456 & $-0,009$ & $-0,014$ \\
\hline$S_{3}$ & & $341^{\circ}$ & & 18,656 & $-0,001$ & $-0,001$ & 74,624 & $-0,006$ & $-0,010$ \\
\hline$S_{4}$ & & $180^{\circ}$ & & 17,658 & $-0,001$ & $-0,001$ & 70,632 & $-0,003$ & $-0,007$ \\
\hline$S_{5}$ & & $19^{\circ}$ & & 18,642 & 0,000 & 0,000 & 74,568 & $-0,001$ & $-0,005$ \\
\hline$S_{6}$ & & $34^{\circ}$ & & 21,335 & 0,000 & 0,000 & 85,34 & 0,002 & $-0,003$ \\
\hline$S_{7}$ & & $45^{\circ}$ & & 25,204 & 0,002 & 0,002 & 100,816 & 0,006 & 0,000 \\
\hline
\end{tabular}

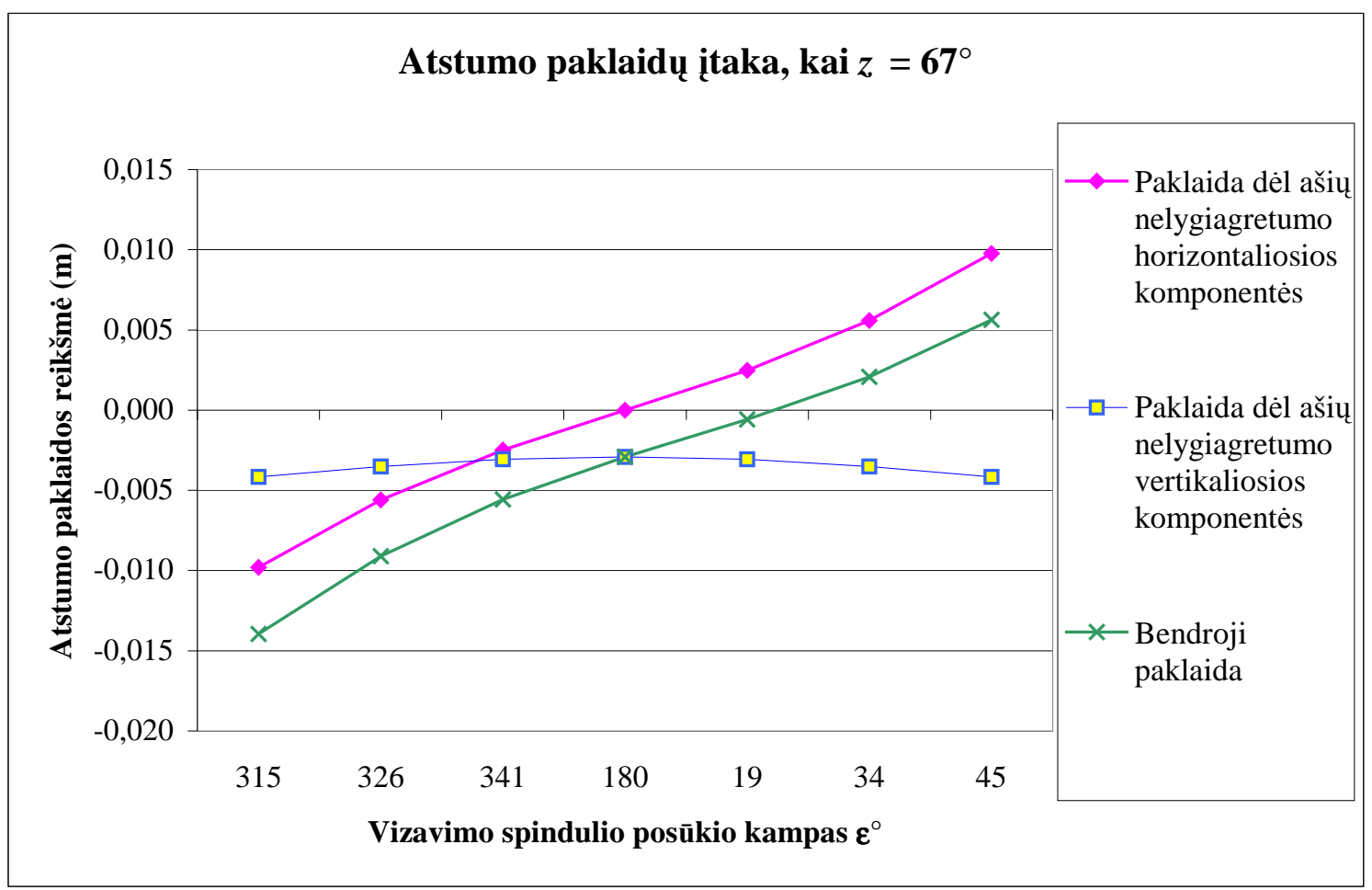

3 pav. Atstumo paklaidos priklausomybès nuo zenitinio kampo grafikas, kai $z=67^{\circ}$.

Fig 3. Graph of dependence of the distance error on the zenith angle, when $z=67^{\circ}$.

Paklaida dèl ašių nelygiagretumo vertikaliosios komponentės neigiama visų linijų - nepriklausomai nuo kampo tarp ašių ir zenitinio kampo dydžio.

Apskaičiavus galima daryti išvadą, kad ašiu nesutapimas turi tiakos matuojamam atstumui, taigi ir koordinatems.

Atliktas ir kitas skaičiuojamasis eksperimentas. Apskaičiuota paklaidų priklausomybè nuo vizavimo linijos zenitinio kampo (3 lentelè). Zenitinio kampo reikšmès pasirinktos $67^{\circ}$ ir $45^{\circ}$. Kampas tarp ašiu nelygiagretumo horizontaliosios ir vertikaliosios komponenčiu $-20^{\prime \prime} .3$ lentelèje pateiktos atstumų pataisos modeliuojant trumpesnius bei ilgesnius atstumus iki pastato (pradinès modeliuotų atstumų reikšmès padidintos 4 kartus). Linijų padètis vietovejje parodyta 2 pav.

Kai zenitiniai kampai skirtingi, nedideliu išmatuotu atstumu paklaida labai nedidelè (3 lentelè). Iš esmès ji itakos neturi. Padidinus pradines atstumų reikšmes paklaidos dalis dideja proporcingai atstumui. 3-5 pav. braižyti esant didesnėms linijų ilgių reikšmèms. Netgi šiuolaikiškų precizinių tolimačių, kurie gali matuoti atstumą iki $170 \mathrm{~m}$ be reflektoriaus prizmių, matavimo paklaida yra leistina nuo $2 \div 5 \mathrm{~mm}$. Ji priklauso nuo matavimų sąlygų ir pasirinktos matavimo programos.

Paklaidos reikšmè dèl ašių nelygiagretumo horizontaliosios komponentès gaunama vienoda. Taip yra todèl, kad skaičiuojant pataisą dèl ašių nelygiagretumo horizontaliosios komponentės skaičiavimo formulèje nèra zenitinio kampo reikšmés.

Skaičiuojant paklaidą dèl ašių nelygiagretumo vertikaliosios komponentès, kai didesni zenitiniai kampai, pataisos reikšmė gaunama mažesnè negu esant mažesniems zenitiniams kampams. Kai $z$ yra $45^{\circ}$, paklaida dèl ašių nelygiagretumo vertikaliosios komponentès gaunama dvigubai didesnè negu kai $z=67^{\circ}$. Bendroji paklaidos reikšmè skiriasi apie 1,5 karto. Ji didesnè, kai zenitinis kampas mažesnis, t. y. $45^{\circ}$. 


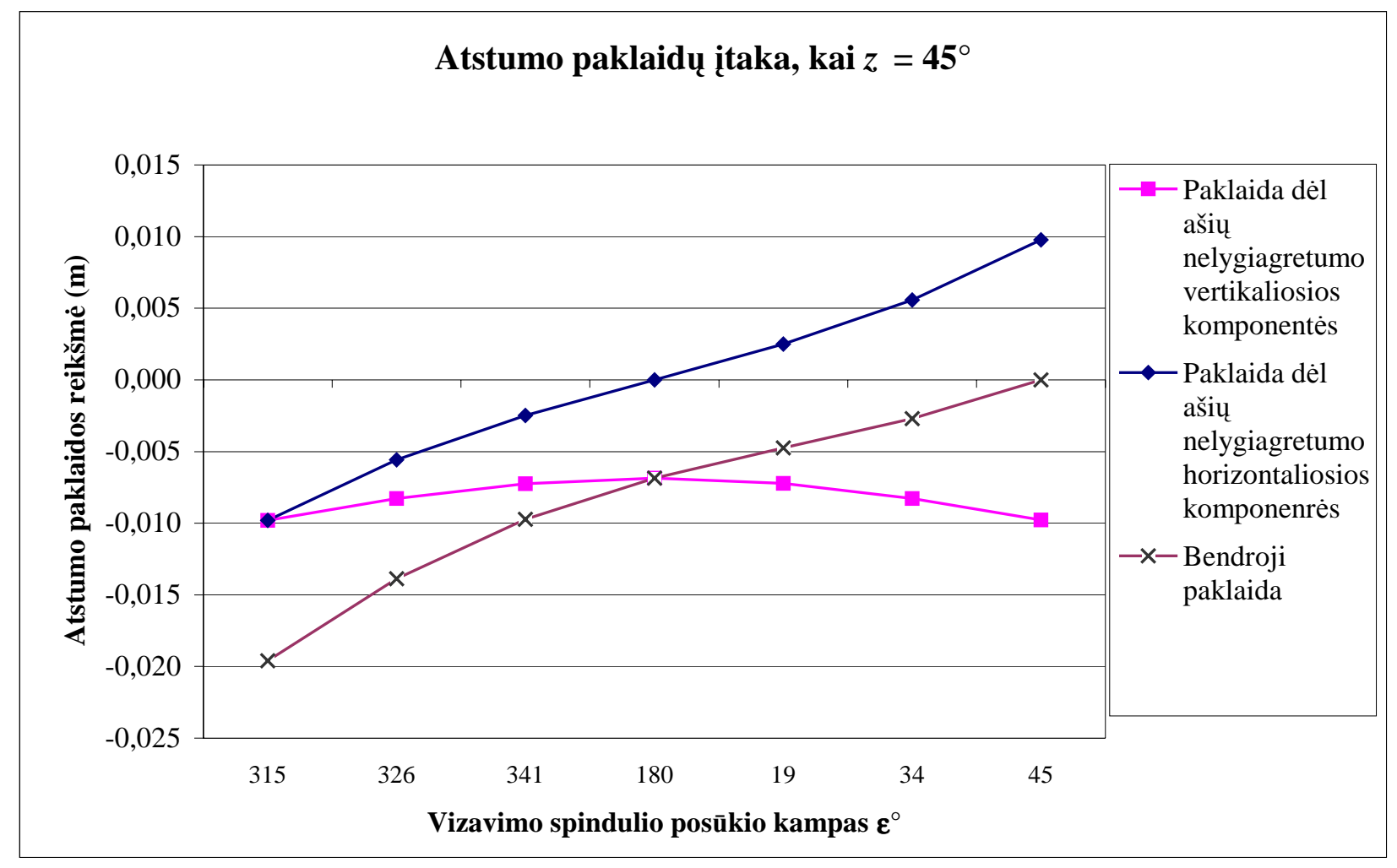

4 pav. Atstumo paklaidos priklausomybès nuo zenitinio kampo grafikas, kai $z=45^{\circ}$.

Fig 4. Graph of dependence of the distance error on the zenith angle, when $z=45^{\circ}$.

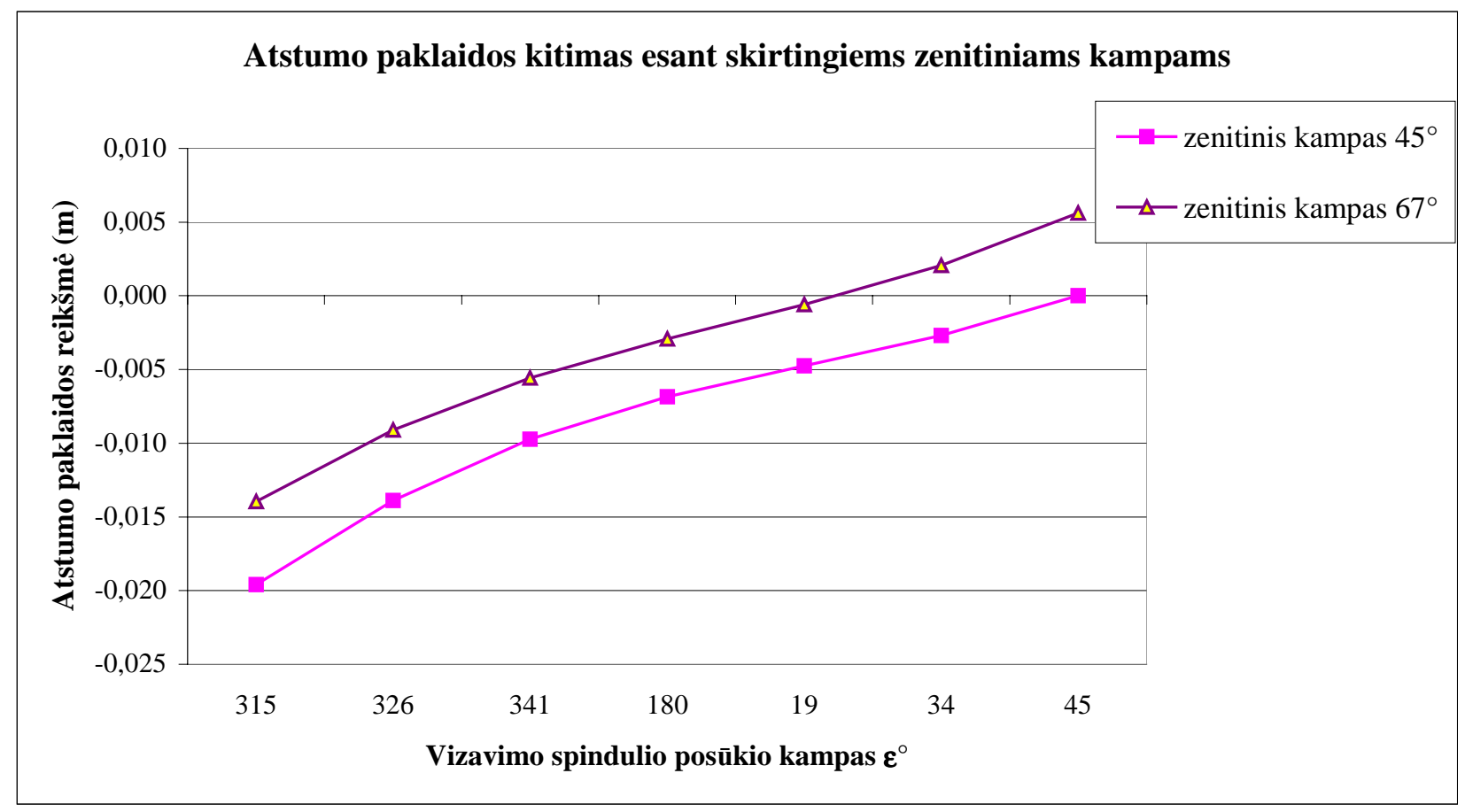

5 pav. Atstumo paklaidos kitimas esant skirtingiems zenitiniams kampams

Fig 5. Variance of the distance error due to different zenith angle

Atstumo paklaidos priklausomybę nuo zenitinio kampo esant skirtingiems $\varepsilon$ kampams galima pavaizduoti grafiškai. Kai zenitinis kampas $z=67^{\circ}$, gautoji paklaidų priklausomybė pavaizduota 3 pav., o kai $z=45^{\circ}, 4$ pav.
Iš 3 pav. ir 3 lentelès matyti, kad paklaidų reikšmès nevienodai kinta 4 matavimo ženklo atžvilgiu. Bendroji atstumo paklaida yra nuo $-14 \mathrm{iki}+6 \mathrm{~mm}$. 
Iš 4 pav. ir 3 lentelès matome, kad paklaida dẻl ašių nelygiagretumo vertikaliosios komponentès yra neigiama ir simetriškai išsidèsčiusi 4 matavimo ženklo atžvilgiu. Zenitinio kampo dydis neturejjo ittakos horizontaliosios paklaidos kitimo intervalui. Ji išlieka tokia pati. Bendroji atstumo paklaida siekia nuo $0 \mathrm{iki}-20 \mathrm{~mm}$.

5 pav. matome, kaip kinta bendros paklaidos dèl ašių nelygiagretumo horizontaliosios ir vertikaliosios komponenčiu, esant skirtingiems zenitiniams kampams. Iš 5 pav. galima teigti, kad grafike pavaizduotos linijos yra lygiagrečios tarpusavyje, tik skiriasi paklaidu reikšmès. Kai $z=67^{\circ}$ - bendrosios atstumo paklaidos kitimo kreivè yra aukščiau negu $45^{\circ}$ kreivè.

Statybos taisyklèse [7] reikalaujama, kad atliekant sienų ir pertvarų montavimo darbus, ašių nuokrypiai nuo projektinių apatiniame arba viršutiniame pjūvyje būtų ne didesni kaip $5 \mathrm{~mm}$, kolonų atraminių paviršių ir atramu altitudžių nuokrypiai nuo projektinių leistini iki $5 \mathrm{~mm}$; pokraninių sijų ašių nesutapimai su projektinėmis - iki $5 \mathrm{~mm}$. Palyginus šiuos statybos normų [7] reikalavimus su gautais tyrimu rezultatais (1-3 lentelès, 3-5 paveikslai), galima daryti išvadą, kad atliekant geodezinius matavimus statybos objektuose būtina ivertinti sistemingąsias matavimo paklaidas, kurias lemia tolimačio ašių nelygiagretumas. Esant tolimačio ašių nelygiagretumui išmatuotus atstumus reikia pataisyti pagal šiame darbe pateiktą metodiką.

\section{Išvados} išvadų:

Atlikus skaičiuojamuosius eksperimentus prieita prie

Skaičiuojant pagal taikomą metodiką [1] gaunama pataisa tik dèl optinès vizavimo ašies, tikrosios vizavimo ašies, atstumų matavimo linijos nelygiagretumo horizontaliosios komponentès lemiamų paklaidų ir visiškai neįvertinama pataisa paklaidų dèl ašių nelygiagretumo vertikaliosios komponentès. Gautas pataisytasis atstumas neatitinka tikrosios jo reikšmės. Visa atstumo pataisa gaunama pagal siūlomą metodiką ivertinus ašių nelygiagretumo horizontaliosios ir vertikaliosios komponenčių bendrają itaką išmatuotam atstumui.

Be reflektoriaus prizmių išmatuotų atstumų pataisos esant tom pačioms nelygiagretumo riboms priklauso nuo vizavimo spindulio zenitinio kampo, kampo tarp sienos plokštumos ir vizavimo spindulio brèžiamos plokštumos bei sienos posvyrio.

Taip pat galima tvirtinti, kad atstumo matavimo paklaida priklauso ne tik nuo tolimačio ašiuc nelygiagretumo, bet ir nuo matavimo sąlygų.

Palyginus gautus rezultatus pagal statybos taisykliu reikalavimus galima daryti išvadą, kad matuojant atstumus būtina įvertinti toliamačio ašių nelygiagretumą.

\section{Literatūra}

1. Buchmann, P. Entwicklung eines Meßsystems zur automatischen polaren Objekterfassung am Beispiel der Bauaufnahme. München: Verlag der Bayerischen Akademie der Wissenschaften, 1996. 84 S.

2. Beckmann, A. Dreidimensionale Koordinatenberechnungen und Transformation. Schriftenreihe der Fachhochschule Neubrandenburg. Fachbereich Bauingeneur und Vermessungwesen. Reihe B: Band 3. Tagungsband zum Seminar am 24. 2000, S. 7-20.

3. Weferling, U. Bauaufnahme als Modellierungsaufgabe. Verlag der Bayerischen Akademie der Wissenschaften, 2002. $170 \mathrm{~S}$.

4. Bagdžiūnaite, R. Building structures measuring errors due to geodetic instruments. Geodesy and Cartography (Geodezija ir kartografija), Vol XXVIII, No 2. Vilnius: Technika, 2002, p 58-65 (in Lithuanian).

5. Bagdžiūnaite, R. Influence of the horizontal eccentricity on geodetic measurements in construction. Geodesy and Cartography (Geodezija ir kartografija), Vol XXVIII, No 4. Vilnius: Technika, 2002, p 145-150 (in Lithuanian).

6. Bagdžiūnaite, R. Corrections to measured distances and coordinates due to unparallelism of main axes of EDM. Geodesy and Cartography (Geodezija ir kartografija), Vol XXIX, No 4. Vilnius: Technika, 2003, p 131-136 (in Lithuanian).

7. General building proceedings. Building rules. (Bendrieji statybos darbai. Statybos taisyklès). ST 2189567.02:2003. Lithuanian builders' association. Vilnius, 2003. 172 p (in Lithuanian). 